\begin{tabular}{|c|c|c|c|c|}
\hline $\begin{array}{c}\text { Prosiding Penelitian \& } \\
\begin{array}{c}\text { Pengabdian Kepada } \\
\text { Masyarakat }\end{array}\end{array}$ & $\begin{array}{c}\text { e ISSN : 2581-1126 } \\
\text { p ISSN : 2442-448X }\end{array}$ & Vol 5, No: 2 & Hal: $102-110$ & Juli 2018 \\
\hline
\end{tabular}

\title{
CONFLICT STAGES BETWEEN PT KERETA API AND BANDUNG CITIZEN
}

\author{
(Study case operation area II Bandung with Tulan west station, kelurahan \\ Jeruk, Kecamatan Andir, Bandung City, West Java)
}

\author{
By: Riany Ambonnari Johani ${ }^{1}$, Soni A. Nulhaqim², Ary Surya Gutama² \\ 1. Graduates of Social welfare undergraduate program \\ 2. Lecturer of social welfare department FISIP Unpad and researcher on study center of conflict resolution FISIP \\ unpad
}

\begin{abstract}
The research background between PT KAI and citizen is due to densely populated area which is one of the citizen phenomena. The purpose of this research is to describe conflict stages that were occurred. This research used theory regarding conflict stages by Simon fisher which will be implicated toward social work and social worker's role on conflict resolution. This qualitative descriptive research used study case technique in which informants are chosen based on purposive sampling such as public figure on society, governmental institution, and other party outside citizen and PT KAI. The research result reveal that pre-conflict firstly triggered by claiming of land by PT KAI toward area of resident on west station citizen. The confrontation started when PT KAI spread letter for land clearing toward West station residents. The situation became intense when PT KAI accompanied by police and soldiers came to residents for clearing of houses. It results into 53 families on west station street loss their home as places to shelter and food stall for living. After conflict, there were involvements of Bandung government, student sympathizers, and society organization for conflict resolution that support this problem to be carried out on legal path. The trial was won by residents of west station. This research suggest that there must be recovery program for residents that loss their home and involvement of parties that had crucial roles on society.
\end{abstract}

Key words: Conflict stages, conflict trigger, conflict resolution

TAHAPAN KONFLIK ANTARA PT KERETA API INDONESIA (KAI) DENGAN WARGA DI KOTA BANDUNG (Studi Kasus PT KAI Daerah Operasi II Bandung dengan Warga Jalan Stasiun Barat Kel. Kebon Jeruk Kec. Andir, Kota Bandung, Jawa Barat)"

\begin{abstract}
ABSTRAK
Penelitian dari konflik antara PT KAI dengan warga ini dilatarbelakangi fenomena kependudukan suatu perkotaan yang padat penduduk. Tujuan dari penelitian ini adalah untuk mendeskripsikan tahapan konflik yang terjadi. Teori yang digunakan adalah teori tentang tahapan konflik dari Simon Fisher yang kemudian diaplikasikan dalam pekerjaan sosial yaitu pekerjaan sosial dalam penanganan konflik dan peran-peran pekerja sosial dalam penanganan konflik sosial. Penelitian deskriptif kualitatif ini menggunakan teknik studi kasus dimana informaninforman ditentukan secara purposive sampling yang meliputi tokoh masyarakat, instansi pemerintah, dan pihak lain diluar warga dan PT KAI. Hasil penelitian menunjukan bahwa Prakonflik pertama kali dipicu oleh klaim lahan yang dilayangkan PT KAI terhadap Warga Jalan Stasiun Barat, Konfrontasi dimulai ketika PT KAI mulai menujukan surat untuk pengosongan lahan kepada Warga Jalan Stasiun Barat, Krisis terjadi saat PT KAI dengan didampingi oleh Polsuska, tentara, polisi, dan Satpol-PP mendatangi pemukiman warga untuk melaksanakan pembongkaran,
\end{abstract}




\begin{tabular}{|c|c|c|c|c|}
\hline $\begin{array}{c}\text { Prosiding Penelitian \& } \\
\begin{array}{c}\text { Pengabdian Kepada } \\
\text { Masyarakat }\end{array}\end{array}$ & $\begin{array}{c}\text { e ISSN : 2581-1126 } \\
\text { p ISSN : 2442-448X }\end{array}$ & Vol 5, No: 2 & Hal: $102-110$ & Juli 2018 \\
\hline
\end{tabular}

Akibat dari krisis yang terjadi adalah 53 KK di Jalan stasiun Barat kehilangan tempat tinggalnya, dan kios jualan, Pascakonflik meliputi adanya keterlibatan pemkot Bandung dalam penyelesaian konflik dan simpatisan mahasiswa dan organisasi kemasyarakatan yang mendukungnya sepakat untuk menempuh jalur hukum. Pengadilan kasus dimenangkan oleh warga. Saran dari penelitian agar dibuat program pemulihan bagi warga yang terkena pembongkaran dan melibatkan pihak-pihak yang memiliki peran dalam masyarakat.

Kata kunci: tahapan konflik, penyebab konflik, penyelesaian konflik

\section{LATAR BELAKANG}

Kepadatan penduduk adalah satu fenomena yang paling sering kita temui di kota-kota besar di Indonesia. Meningkatnya pertumbuhan penduduk dan tingginya arus urbanisasi menjadi salah satu faktor utama penyebab terjadinya fenomena tersebut. Namun, pada kenyatannya ketidaksiapan kota terutama dari segi infrastruktur yang ada membangkitkan banyak persoalan utama. Selain permasalahan infrastruktur, permasalahan lahan pemukiman di suatu kota yang minim dengan tingginya angka urbanisasi yang ada menyebabkan ketimpangan di antara dua hal tersebut.

Menurut data Survei Sosial Ekonomi Nasional (Susenas) pada Maret 2016, Provinsi Jawa Barat didiami penduduk sebanyak 43.053.732 jiwa. Penduduk ini tersebar di 27 Kabupaten/Kota, 625 Kecamatan dan 5.899 Desa/Kelurahan. Data tersebut pun baru ditambah dengan Kabupaten Pangandaran yang baru resmi dimekarkan dengan jumlah penduduk tahun 2014 sebanyak 450.658 jiwa. Di Kota Bandung sendiri, penduduk yang tinggal sebanyak 2.748.733 jiwa.

Menilik dari data statistik tersebut, Kota Bandung termasuk salah satu kota yang padat penduduknya. Hal ini mengingat luas wilayah Kota Bandung yang hanya $1756,65 \mathrm{~km}^{2}$ atau $4,73 \%$ dari luas provinsi Jawa Barat yang luasnya adalah $37173,97 \mathrm{~km}^{2}$ dan Kota Bandung didiami oleh 3.178.543 jiwa penduduk. Menurut data statistik kependudukan khusus Kota Bandung tahun 2014, angka kepadatan Kota Bandung sebesar 15.713 jiwa/km². (sumber: http://jabar.bps.go.id)

Padatnya penduduk di Kota Bandung membuat harga jual dan nilai guna lahan naik drastis. Hal tersebut membuat lahan di Kota Bandung banyak diperebutkan oleh berbagai pihak. Tidak menghenrankan jika banyak konflik-konflik yang terjadi, dan seperti yang tertera pada table tersebut, umunya disebabkan oleh persengketaan lahan.

Pada penelitian kali ini, peneliti juga mengangkat konflik sosial yang terjadi pada satu BUMN dengan kelompok masyarakat. Konflik kali ini terjadi pada PT Kereta Api Indonesia (KAI) dan Warga Jalan Stasiun Barat, Kelurahan Kebon Jeruk, Kecamatan Andir, Kota Bandung, Jawa Barat. Lahan yang mereka tinggali selama ini memang adalah milik PT KAI. Tetapi, puluhan tahun sudah mereka menjalani kehidupan di atas lahan tersebut. Mulai dari tinggal, mencari nafkah, dan melakukan aktivitas sehari-hari lainnya. Bahkan, beberapa pihak yang mendiami lahan tersebut pun ada yang bekerja sebagai karyawan PT KAI sendiri. Selama bertahuntahun tersebut, tidak ada tindakan dari PT KAI sebagai wujud kepemilikan lahan warga tersebut ilegal. Baru saat ini proses penggusuran atas dasar klaim lahan PT KAI tersebut dilakukan.

Konflik sosial yang terjadi ini merupakan salah satu dampak dari masalah sosial yang terjadi di Kota Bandung. Warga yang tergusur merasa sangat dirugikan karena mereka merasa lahan hunian yang mereka tempati sekarang sudah strategis dan nyaman.

Jika mengacu pada Undang-Undang (UU) No. 23 Tahun 2007 tentang Perkeretaapian, maka batas bangunan dengan rel kereta minimal 21 meter. Penerapan aturan tersebut pun sudah diminimalisir oleh PT KAI guna mengurangi penggusuranpenggusuran pemukiman yang diharuskan. Pihak PT KAI mengatakan saat ini cukup membutuhkan 12 meter lahan di setiap pinggiran rel.

Di Kota Bandung Provinsi Jawa Barat, tepatnya di Jalan Stasiun Barat, Kelurahan Kebon Jeruk, Kecamatan Andir, 57 kepala keluarga terkena dampak dari penggusuran lahan ini. Penggusuran dilakukan dengan menurunkan ratusan personel aparat kepolisian dengan tiga alat berat. Warga 
Prosiding Penelitian \&

Pengabdian Kepada

Masyarakat e ISSN : 2581-1126

p ISSN : 2442-448X
Vol 5, No: 2
Hal: $102-110$
Juli 2018 yang berunjuk rasa menyuarakan akan kejelasan tempat tinggal dan mata pencaharian yang hilang pasca dilakukannya penggusuran oleh PT KAI. Hal ini menyebabkan mereka kehilangan dua hal tersebut sekaligus. Tidak hanya berunjuk rasa, warga juga menutup Jalan Sukabumi dimana unjuk rasa tersebut terjadi. Mereka juga memasang beberapa spanduk yang menyuarakan aspirasi mereka.

Pada konflik yang terjadi antara PT KAI dengan warga, penulis ingin melihat bagaimana tahapan konflik yang terjadi. Dengan menggunakan teori penahapan konflik Fisher, penulis ingin meneliti bagaimana perkembangan konflik dari awal muncul sampai ke tahap penyelesaian. Penulis juga ingin meneliti bagaimana peran pihak-pihak lain diluar PT KAI dan Warga Jalan Stasiun Barat selama konflik terjadi. Fenomena konflik yang terjadi antara PT KAI Daop II Bandung dengan Warga Jalan Stasiun Barat, Kelurahan Kebon Jeruk, Kecamatan Andir, Kota Bandung ini menjadi tempat studi kasus yang diangkat oleh peneliti untuk melakukan penelitian ini.

Penelitian ini difokuskan kepada warga yang menjadi sasaran pembongkaran oleh PT KAI. Fokus penelitian kepada masyarakat dilakukan dengan mengangkat teori dari beberapa ahli mengenai tahapan konflik, peran pekerja sosial, dan metode pekerjaan sosial beserta model intervensinya. Teori tahapan konflik yang akan dibahas berangkat dari teori Simon Fisher yang mengelompokan strata konflik menjadi 5 tingkatan. Selanjutnya, teori mengenai peran pekerjaan sosial yang dikemukakan oleh Charles Zastrow, penelitian ini juga dilakukan untuk mendeskripsikan bagaimana peran pekerja sosial dalam penanganan konflik sosial beserta metode dan model praktik yang bisa dilakukan berangkat dari teori Rothman dan Tropman.

Penulis menggunakan metode $C O / C D$ (Community Organization/Community Development) yang bertujuan untuk memperbaiki kualitas hidup masyarakat. Perbaikan kualitas hidup masyarakat yang dimaksud adalah pemulihan terhadap kondisi Warga Jalan Stasiun Barat yang terkena pembongkaran pemukiman tempat tinggalnya oleh PT KAI. Pemulihan kondisi tersebut dilakukan melalui pendayaagunaan sumber-sumber yang ada di dalam masyarakat serta menekankan dengan adanya prinsip peran serta atau partisipasi masyarakat.

Melalui metode pekerjaan sosial CO/CD (Community Organization/Community
Development)yang akan digunakan pada penelitian ini, penulis juga akan menggunakan model praktek intervensi komunitas dari teori Rothman dan Tropman, yaitu Locality Development yang nantinya akan membantu penulis dalam proses pemulihan kondisi Warga Jalan Stasiun Barat yang telah terkena pembongkaran tempat tingggal oleh PT KAI.

\section{TINJAUAN PUSTAKA}

Konflik dalam masyarakat seringkali terjadi, hal ini dikarenakan setiap kelompok masyarakat memiliki pandangan, keyakinan dan kepentingan yang berbeda-beda. Konflik antar warga dikenal dengan konflik horizontal. Konflik dalam bentuk ini dapat dipicu oleh berbagai sebab. Konflik yang terjadi antara PT KAI Daop II Bandung dengan Warga Jalan Stasiun Barat, Kelurahan Kebon Jeruk, Kecamatan Andir, Kota Bandung, Jawa Barat dipicu oleh sengketa lahan. Warga yang telah puluhan tahun menempati lahan PT KAI di daerah Bandung ini menolak untuk digusur karena akan kehilangan mata pencaharian dan tempat tinggal mereka dimana dua hal tersebut adalah faktor utama penyokong kehidupan mereka.

Penelitian ini akan menerapkan tahapan konflik yang telah dilakukan melalui tahapan konflik yang terjadi, karena konflik dapat berubah setiap saat, melalui tahap aktivitas, intensitas dan ketegangan yang terjadi, tahapan konflik ini merupakan salah satu alat bantu untuk bisa mengetahui akar penyebab yang melatarbelakangi terjadinya konflik, dan mengetahuin dimana posisi konflik sekarang berada. Sehingga mengetahui tindakan yang sesuai untuk dilakukannya penyelesaian.

Tahapan konflik tersebut, yaitu adalah prakonflik, konfrontasi, krisis, akibat, dan pascakonflik. Pada tahapan prakonflik akan diidentifikasi gejala-gejala yang timbul karena perbedaan kepentingan dari 2 pihak yang berkonflik. Pada tahap konfrontasi konflik akan mulai terasa dan muncul ke permukaan. Pada tahap krisis ketegangan akan dapat dirasakan karena tahap ini merupakan tahapan puncak konflik terjadi. Pada tahap akibat akan terlihat bagaimana dampak dari krisis yang terjadi. Pada tahap pascakonflik konflik sudah meredam dan kondisi kedua pihak mulai normal kembali. 


\begin{tabular}{|c|c|c|c|c|}
\hline $\begin{array}{c}\text { Prosiding Penelitian \& } \\
\begin{array}{c}\text { Pengabdian Kepada } \\
\text { Masyarakat }\end{array}\end{array}$ & $\begin{array}{c}\text { e ISSN : 2581-1126 } \\
\text { p ISSN : 2442-448X }\end{array}$ & Vol 5, No: 2 & Hal: $102-110$ & Juli 2018 \\
\hline
\end{tabular}

\section{METODE PENELITIAN}

Penelitian yang akan dilakukan ini menggunakan pendekatan kualitatif. Menurut Creswell (2007:15) penelitian kualitatif merupakan metode-metode untuk mengeksplorasi dan memahami makna yang oleh sejumlah individu atau sekelompok orang dianggap berasal dari masalah sosial atau kemanusiaan. Penelitian dengan menggunakan pendekatan kualitatif diharapkan dapat menghasilkan uraian yang mendalam tentang ucapan, tulisan, atau perilaku yang diamati dari subjek penelitian, bisa dari individu, kelompok, masyarakat, atau organisasi tertentu dalam suatu konteks tertentu yang dikaji dari sudut pandang yang utuh, komprehensif, dan holistik. Creswell (2007) memberikan penjelasan lebih detail tentang penelitian dengan pendekatan kualitatif.

"Pendekatan kualitatif adalah pendekatan untuk membangun pernyataan pengetahuan berdasarkan perspektif-konstruktif (misalnya, makna-makna yang bersumber dari pengalaman individu, nilai-nilai sosial dan sejarah, dengan tujuan untuk membangun teori atau pola pengetahuan tertentu), atau berdasarkan perspektif partisipatori (misalnya: orientasi terhadap politik, isu, kolaborasi, atau perubahan), atau keduanya." (Creswell 2007:18)

Penelitian kualitatif menggunakan lingkungan alamiah sebagai sumber data. Peristiwaperistiwa yang terjadi dalam suatu situasi sosial merupakan kajian utama dari penelitian ini. Hakikat pemaparan data pada umumnya menjawab pertanyaan-pertanyaan mengapa dan bagaimana suatu fenomena bisa terjadi. Tujuan umum dari pada penelitian kualitatif yakni mencakup informasi tentang fenomena utama yang dieksplorasi dalam penelitian, partisipan penelitian, dan lokasi penelitian (Creswell 2007:57).

Pada penelitian ini pendekatan kualitatif diambil untuk memahami masalah sosial berdasarkan pada penciptaan gambaran holistik yang nantinya akan dibentuk dalam rangkaian pandangan informan secara terperinci sehingga peneliti nantinya dapat dengan sistematis dan lengkap menggambarkan hubungan antara teori dengan fakta-fakta di lapangan mengenai konflik yang terjadi antara PT KAI Daop II Bandung dengan Warga Jalan Stasiun Barat, Kelurahan Kebon Jeruk, Kecamatan Andir, Kota Bandung, Jawa Barat. Diharapkan dengan menggunakan pendekatan ini maka peneliti akan dapat memahami kondisi antara subjek penelitian, objek penelitian, serta calon informan dengan mendalam, mengingat tema yang diambil berkaitan dengan konflik sosial dimana peneliti harus memahami betul situasi dan kondisi sosial yang ada di lapangan secara menyeluruh.

Teknik penelitian yang digunakan adalah studi kasus. Dengan studi kasus, diharapkan dapat memperoleh informasi mendalam mengenai subjek yang akan diteliti dan meperoleh gambaran lengkap mengenai resolusi konflik antara PT KAI Daop II Bandung dengan Warga Jalan Sukabumi Kecamatan Batununggal, Kota Bandung, Jawa Barat. Creswell (2007) menjelaskan:

Studi kasus merupakan strategi penelitian di mana di dalamnya peneliti menyelidiki secara cermat suatu program, peristiwa, aktivitas, proses, atau sekelompok individu.Kasus-kasus dibatasi oleh waktu dan aktivitas, dan peneliti mengumpulkan informasi secara lengkap dengan menggunakan berbagai prosedur pengumpulan data berdasarkan waktu yang telah ditentukan. (Creswell, 2007)

Tentunya metode ini sangat sesuai dengan tema penelitian ini yang mengangkat tentang konflik sosial. Dengan metode ini diharapkan akan dipahami bagaimana fenomena konflik yang terjadi antara pihak industri BUMN dengan warga ini secara mendalam dari menggali sumber informasi kepada informan-informan yang merupakan target dari observasi yang akan dilakukan.

\section{HASIL DAN PEMBAHASAN}

\section{Prakonflik}

Konflik antara PT KAI dan Warga Jalan Stasiun Barat memang dilatarbelakangi oleh perbedaan persepsi kepemilikan lahan. Tetapi, konflik ini bukan merupakan konflik persengketaan lahan. Seperti yang lumrah kita ketahui, konflik persengketaan lahan akan terjadi apabila kedua 
Prosiding Penelitian \&

Pengabdian Kepada

Masyarakat e ISSN : 2581-1126

p ISSN : 2442-448X
Vol 5, No: 2
Hal: $102-110$

Juli 2018

belah pihak memiliki sertifikat kepemilikan tanah yang otentik sifatnya.

Pada konflik yang terjadi antara PT KAI dan Warga Jalan Stasiun Barat, kedua pihak yang berseteru sama-sama tidak memiliki bukti kepemilikan lahan yang otentik. PT KAI mengklaim kepemilikan lahan hanya dengan surat hak guna pakai saha yang itupun sebenarnya sudah habis masa berlakunya.

Seharusnya, PT KAI maupun Warga Jalan Stasiun Barat tidak berhak untuk mengusir satu sama lain. Mengingat tanah yang ada di Jalan Stasiun Barat posisinya tidak bertuan atau status quo. Tetapi, yang dilakukan PT KAI terhadap Warga Jalan Stasiun Barat justru menentang peraturan yang sudah ada. Di awal pengklaiman PT KAI hanya menunjukan bukti kepemilikan tanah yang dinilai kurang valid oleh warga. Warga pun acuh akan hal tersebut.

Pada fase ini, sudah bisa dilihat bahwa potensi konflik bisa berlanjut di masa yang akan datang. Kemungkinan terjadi konfrontasi sudah bisa diramalkan dari pengklaiman lahan dari PT KAI yang pasti akan melakukan tindakan untuk merebut tanah itu seutuhnya dari Warga Jalan Stasiun Barat. Klaim yang dilayangkan pada awalnya, tentu tidak hanya bermaksud untuk mengonformasikan, tetapi ada hasrat untuk memiliki secara utuh.

Dikarenakan pada tahapan ini konflik belum muncul ke permukaan, pihak-pihak lain yang terlibat selain PT KAI dan warga pun belum melakukan intervensi di konflik tersebut. Pihak-pihak lainnya hanya sebagai perantara antara kedua belah pihak yang berkonflik. Pihak lain diluar yang berkonflik belum pada tahapan memediasi.

Misalnya, kepala RT. 003 dan Kepala RW. 02, Kelurahan Kebon Jeruk, Kecamatan Andir, Kota Bandung, Pak Sholeh. Pak Sholeh dan Pak Arman pada tahap prakonflik hanya sebagai penyampai pesan dari PT KAI dan sebaliknya.Walaupun tandatanda adanya konflik sudah muncul ke permukaan, tetapi kedua pihak dan relasinya belum saling bergerak.

Pihak Bhabinsa dan Bhabinkantibmas pun baru hanya mendampingi kedua pihak tanpa ada intervensi lain. Baik yang sifatnya berimbang atau berat sebelah.

Dalam tahap ini peran pekerja sosial yang dapat dianalisis adalah sebagai fasilitator, kerena pihak ketiga yang berperan pada tahap prakonflik berperan sebagai perantara dan tidak memediasi kedua pihak yang berkonflik. Pihak ketiga memiliki tanggung jawab untuk merencanakan dan mengimplementasikan cara untuk meningkatkan pelayanan kepada klien.

\section{Konfrontasi}

Dalam konfrontasi, konflik menjadi semakin terbuka. Jika pada awalnya hanya satu pihak yang merasa ada masalah, pada tahap ini pihak lain mulai menyadari ada potensi untuk berselesih ke intensitas yang lebih besar. Masing-masing pihak mungkin mulai melakukan aksi dan mengumpulkan masa untuk mendukung kubunya.

Pada konfrontasi yang terjadi antara PT KAI dan Warga Jalan Stasiun Barat, PT KAI mulai meminta warga untuk mengosongkan lahannya. PT KAI juga mulai membawa beberapa aparat saat mengunjungi Warga Jalan Stasiun Barat walaupun tidak banyak jumlahnya.

Warga Jalan Stasiun Barat juga mulai pasang badan di tahapan ini. Mereka mulai berstrategi di kubunya untuk meredam permasalahan yang ada. Maka, sempatlah diadakan beberapa kali musyawarah dengan pihak PT KAI didampingi pihak ke 3. Namun, hasil keputusannya nihil. Kedua pihak tetap merasa lahannya adalah milik masing-masing.

Pada tahapan ini juga kedua pihak mulai merasa harus memperkuat kubunya masing-masing. Baik PT KAI dan Warga Jalan Stasiun Barat samasama mengantisipasi kemungkinan terburuk yang akan terjadi ke depannya.

Pihak lain yang terlibat sebagai pihak ke 3 juga mulai mengintervensi untuk memediasi antara kedua pihak yang berseteru. Saat diadakannya musyawarah, Pihak Bhabinkantibmas dan Bhabinsa datang untuk mengawal jalannya musyawarah. Perwakilan dari RT dan RW juga memediasi pihak yang berseteru agar mengurangi intensitas konflik berlanjut kea rah yang lebih serius atau untuk menghindari krisis.

Pada tahap ini, hubungan di antara kedua pihak menjadi sangat tegang., mengarah pada polarisasi di antara pendukung di masing-masing pihak.

Pihak ketiga pada tahap ini berperan sebagai mediator, perwakilan dari RT, RW serta penanggungjawab keamanan yang meliputi Babinsa dan Bhabinkamtibmas menyelenggarakan musyawarah guna mencarui resolusi dari konflik tersebut. Pada tahap ini pihak ketiga memiliki peran untuk menengahi kedua pihak yang berkonflik 
Prosiding Penelitian \&

Pengabdian Kepada

Masyarakat e ISSN : 2581-1126

p ISSN : 2442-448X
Vol 5, No: 2
Hal: $102-110$ selama berjalannya musyawarah dalam artiam pihak ketiga mengontrol jalannya musyawarah antara PT KAI dan Warga Jalan Stasiun Barat.

Pihak ketiga juga berperan menjadi fasilitator karena memiliki tanggung jawab untuk merencanakan dan mengimplementasikan cara untuk meningkatkan pelayanan. Termasuk juga dalam melibatkan diri dalam bekerja kolaboratif dengan pihak lain untuk memfasilitasi.

\section{Krisis}

Krisis merupakan puncak dari konflik. Ketegangan dan/atau kekerasan terjadi paling hebat. Konflik paling hebat terjadi saat dilakukannya pembongkaran oleh PT KAI terhadap rumah-rumah Warga Jalan Stasiun Barat. Pada fase ini PT KAI mengerahkan kubunya untuk mengintimidasi Warga Jalan Stasiun Barat dengan melakukan pembongkaran yang disetujui oleh secara sepihak saja.

PT KAI membawa dukungan hingga mencapai 1300 orang. Pihak yang mendukung PT KAI tersebut termasuk dengan Polsuska, Satpol-PP, tentara, dan para polisi. PT KAI membawa beberapa pihak luar untuk memperkuat kubunya saat bertikai dengan warga. Sedangkan, jumlah Warga Jalan Stasiun Barat saat itu hanya mencapai kurang lebih seratus orang.

Pada tahapan ini, Bhabinkantibmas dan Bhabinsa hanya melakukan pemantauan dan antisipasi pengamanan kepada warga tergusur dari jauh saja. Kedua aliansi aparat ini hanya mengantisipasi jika ada ricuh hebat antara PT KAI dan Warga Jalan Stasiun Barat. Saat terjadi krisis mereka tidak mengintervensi.

Kepala RT.003 dan kepala RT. 02 mencoba bernegoisiasi kepada PT KAI untuk mengangguhka PT KAI. Dalam kejadian ini, Pihak RT dan RW menjalankan cara penyelesaian konflik berupa negoisiasi.

Saat krisis terjadi, warga merasa tidak berdaya karena kalah jumlah dengan pasukan PT KAI sehingga mereka hanya bisa melakukan perlawanan kecil dengan melempari batu kerikil kea rah pasukan PT KAI yang melakukan pembongkaran di Jalan Stasiun Barat.

Pada tahap ini peran pihak ketiga adalah sebagai mediator karena pihak ketiga berusaha menengahi kedua pihak yang berkonflik. Sedangkan, wewenang penuh saat kejadian krisis diambil alih spenuhnya oleh PT KAI.

\section{Akibat}

Akibat yang ditimbulkan dari krisis yang terjadi adalah warga yang menjadi korban pembongkaran kehilangan tempat tinggalnya. Ada sekitar 53 KK yang luntang lantung kehilangan tempat tinggal mereka. Ada sekitar 50an rumah pula yang terbongkar oleh pihak PT KAI, termasuk juga 23 kios tempat berjualan waga.

Dikarenakannya tidak ada peringatan yang pasti dari PT KAI sebelum melakukan pembongkaran pemukiman warga di Jalan Stasiun Barat, kerugian materi yang diderita warga pun jumlahnya mencapai ratusan juta. Hal ini dikarenakan Warga Jalan Stasiun Barat belum sempat mengamankan dan mengosongkan tempat tinggalnya sebelum rumah mereka dibongkar. Alhasil, kerugian warga tersebut tidak hanya pada bangunan rumah yang terbongkar, tetapi juga pada barang-barang, perlengkapan rumah tangga, furnitur, dan alat-alat lainnya. Termasuk juga perlengkapan dan barang-barang yang digunakan untuk berjualan di kios-kios mereka.

Warga hanya sempat mengamankan diri mereka dan keluarga masing-masing sebelum satu persatu bangunan rumah di Jalan Stasiun Barat dibongkar oleh pihak PT KAI. Ada beberapa warga yang sempat menyelamatkan barang-barang berharganya, tetapi itu hanya sepersekian dari keseluruhan barangnya atau tidak seberap dan tidak banyak warga lainnya yang sempat melakukan penyelamatan terhadap barang-barangnya walaupun hanya sedikit. Oleh karena itu, banyak warga yang kehilangan segala hartanya pasca pembongkaran yang dilakukan oleh PT KAI. Mereka tidak sempat menyelamatkan apapun selain diri mereka sendiri.

Pada tahapan ini pula, PT KAI memasang patok pagar pembatas wilayah sebagai bentuk penegasan akan tanah mereka. Saat pemasangan patok, pihak PT KAI didampingi oleh beberapa tentara yang dilengkapi dengan senjata laras panjang sehingga warga enggan untuk melawan.

Pada fase ini, pihak lain seperti Bhabinkantibmas dan Bhabinsa membantu warga terkait pendirian tenda dan penyaluran bantuan makanan dari Dinsos Bandung. Mereka ikut membantu warga hingga jelang seminggu pasca pembongkaran. 
Prosiding Penelitian \&

Pengabdian Kepada

Masyarakat e ISSN : 2581-1126

p ISSN : 2442-448X
Vol 5, No: 2
Hal: $102-110$
Kemudian, pada tahapan ini lah aliansi mahasiswa mulai masuk mengintervensi konflik. Simpatisan mahasiswa dan organisasi SORAK datang ke Jalan Stasiun Barat 3 hari pasca pembongkaran. Mereka membantu Warga Jalan Stasiun Barat untuk bantuan makanan dan obat-obatan serta selimut.

Simpatisan mahasiswa dan organisasi juga turut berperan dalam mendampingi warga. Misalnya, dengan mendukung penuh melakukan aksi sosial bersama warga sebagai kontrol sosial terhadap konflik yang sedang terjadi. Pihak mahasiswa dan organisasi juga membela penuh warga dan berusaha mendampingi terus warga untuk mendapatkan haknya dan menegakkan keadilan.

Proses pendampingan yang dilakukan pihak ketiga masuk ke dalam kategori peran pekerja sosial sebagai advokat dimana pihak ketiga mengintervensi advokasi atau pendampingan di jalur hukum untuk mengadvokasi legislasi dan kebijakan untuk memenuhi keadilan sosial.

\section{Pascakonflik}

Pada tahap pascakonflik, situasi diselesaikan dengan cara mengakhiri berbagai konfrontasi, kekerasan dan ketegangan.

Warga Jalan Stasiun Barat mencoba menyelesaikan ketegangan dengan memusyawarahkan konflik yang terjadi dengan Pemkot Bandung. 3 hari pasca pembongkaran, warga pergi ke pendopo Kota Bandung untuk menemui Pemkot Bandung. Dari pertemuan tersebut, tercetus 4 janji Pemkot Bandung diwakili Walikota, Ridwan Kamil untuk menolong warga. 4 janji tersebut antara lain:

1. Pemkot Bandung akan merelokasi warga tidak jauh dari pemukiman mereka di Jalan Stasiun Barat.

2. Pemkot Bandung akan meminjamkan modal usaha 30juta/orang kepada Warga Jalan Stasiun Barat.

3. Pemkot Bandung akan membangun rusunawa untuk warga yang terkena pembongkaran (di Rancacili dan Sadangserang)

4. Pemkot Bandung akan mendampingi warga untuk menempuh jalan hukum

Namun, 4 bulan sejak janji itu dibuat belum ada realisasi dari Pemkot Bandung untuk menepati janjinya tersebut. akhirnya, warga dengan didampingi simpatisan mahasiswa dan organisasi sepakat untuk memanggil kuasa hukum dan menyeret kasusnya ke pengadilan.
Rangkaian sidang peradilan pun dimulai sejak bulan Oktober 2016. PT KAI sebagai tergugat sering kali mangkir dari siding yang dilaksanakan. Setelah melaksanakan belasan kali siding peradilan selama kurun waktu 8 bulan, warga memenangkan kasus tersebut. Hakim Pengadilan Negeri Bandung Kelas 1A mengabulkan gugatan Warga Jalan Stasiun Barat kepada PT KAI. PT KAI pun dikenakan kewajiban untuk ganti rugi berupa materi kepada warga.

Pada tahapan ini, aparat keamanan Bhabinkantibmas dan Bhabinsa tidak turut mengintervensi ke dalam konflik yang terjadi. Mereka menganggap konflik ini sudah merupakan supremasi hukum dan menyerahkan sepenuhnya kasus ini ke pengadilan.

Selang seminggu pasca menangnya Warga Jalan Stasiun Barat di pengadilan, mereka mulai mengukur kembali lahan mereka untuk membagi wilayah tempat tinggal tiap-tiap warga. Saat sedang melakukan pengukuran tersebut, datang pihak PT KAI didampingi Polsuska untuk menghentikan kegiatan yang sedang dilakukan warga. Warga tidak terima sehingga sempat terjadi adu dorong. PT KAI juga merobek spanduk-spanduk yang di pasang oleh warga.

Ketika hal tersebut terjadi, tidak ada perwakilan RT dan RW maupun aparat keamanan Bhabinkantibmas dan Bhabinsa yang mendmpingi. Spontanitas kedatangan PT KAI dan Polsuska mungkin menjadi penyebab dari hal tersebut. sehingga pada tahap ini damapt disimpulkan bahwa PT KAI tidak menjaga kesepakatan yang telah diambil.

Pihak ketiga pada fase ini berperan sebagai fasilitator. Pada tahap ini, pihak ketiga bekerja kolaboratif dengan pihak lainnya untuk memfasilitasi warga di jalan hukum. Secara otomatis pihak ketiga yang mendampingi warga juga memiliki peranan sebagai advokat.

\section{KESIMPULAN DAN SARAN}

\section{Kesimpulan}

Konflik yang terjadi antara PT KAI dengan Warga Jalan Stasiun Barat adalah sebagai insiden konflik kekerasn yang tergolong besar dan bersifat horizontal.Konflik dilatarbelakangi oleh klaim lahan yang tiba-tiba dilatarbelakangi oleh PT KAI tanpa bukti yang otentik.Setelah klaim PT KAI melakukan 
Prosiding Penelitian \&

Pengabdian Kepada

Masyarakat e ISSN : 2581-1126

p ISSN : 2442-448X

Hal: $102-110$

Juli 2018

pembongkaran rumah-rumah warga tanpa melalui pengadilan terlebih dahulu.Tindakan ini merupakan bentuk intimidasi.

Berdasarkan hasil penelitian dan pembahasan yang telah diuraikan penulis pada bab sebelumnya, dapat disimpulkan bahwa:

1. Prakonflik pertama kali dipicu oleh klaim lahan yang dilayangkan PT KAI terhadap Warga Jalan Stasiun Barat. Pada fase ini, warga masih bersifat acuh. Warga juga belum didampingi pihak lain untuk berkonflik. Konflik pada tahapan ini belum terlalu terlihat ke permukaan

2. Konfrontasi dimulai ketika PT KAI mulai menujukan surat untuk pengosongan lahan kepada Warga Jalan Stasiun Barat. Warga mulai merespon PT KAI. sempat digelar beberapa kali musyawarah untuk mencari jalan keluar dan kesepakatan kedua belah pihak pada konflik ini. Namun, tidak ada jalan keluar yang disepakati. Pada tahap ini lembaga pemerintah seperti RT dan RW turut hadir sebagai penengah dari kedua pihak. Aparat keamanan daerah, Bhabinkantibmas dan Bhabinsa juga mendampingi jalannya musyawarah yang digelar selama proses konfrontasi sebagai kontrol dan antisipasi jika terjadi ricuh

3. Krisis terjadi saat akhirnya PT KAI dengan didampingi oleh Polsuska, tentara, polisi, dan Satpol-PP yang jumlahnya diperkirakan mencapai 1300 orang mendatangi pemukiman warga di Jalan Stasiun Barat untuk melaksanakan pembongkaran tanpa pemberitahuan terlebih dahulu terkait tanggal pembongkaran kepada warga. Warga yang kalah jumlah akhirnya melakukan perlawanan sekedarnya dengan melempari batu ke arah pihak PT KAI. Perwakilan RT dan RW pada tahap ini ada dipihak warga dan turut menyuarakan argument warga. Sedangkan, aparat keamanan daerah, Bhabinkantibams dan Bhabinsa hanya melakukan kontrol dari jarak jauh

4. Akibat dari krisis yang terjadi adalah $53 \mathrm{KK}$ di Jalan stasiun Barat kehilangan tempat tinggalnya, dan kios jualan mereka. Krisis juga menelan korban jiwa sebanyaj 4 orang secara tidak langsung. Pasca krisis, Warga Jalan Stasiun Barat mendapat bantuan materi dan dukungan dari simpatisan mahasiswa dari beberapa ikatan universitas dan aliansi. Warga didampingi simpatisan mahasiwa dan organisasi mendatangi pendopo Walikota Bandung untuk menuntut keadilan mereka. Tercetuslah 4 janji dari Pemkot untuk menolong warga menuntut kembali haknya.

5. Pascakonflik dimulai saat ketegangan Warga Jalan Stasiun Barat dan PT KAI mulai perlahan mereda karena warga berharap penuh akan janji Pemkot Bandung. Namun, selang 4 bulan dari janji tersebut belum ada yang teralisasi sama sekali sehingga warga dan simpatisan mahasiswa dan organisasi yang mendukungnya sepakat untuk menempuh jalur hukum. Pengadilan kasus dimenangkan oleh warga. Pada tahapan ini, Bhabinkantibmas dan Bhabinsa tidak ikut campur tangan sama sekali karena telah menyerahkan sepenuhnya ke pengadilan. Perwakilan pemerintah dari RT dan RW tetap mendukung warga selama berjalannya sidang peradilan yang digelar di Pengadilan Negeri Kelas 1A Bandung.

Temuan konflik ini menunjukkan bahwa konflik sosial antar masyarakat merupakan insiden yang tergolong besar dan dapat merugikan banyak pihak. Konflik ini telah banyak merugikan bukan hanya Warga Jalan Stasiun Barat, tetapi juga pihak lain yang ada di lingkungan sekitarnya. Namun nyatanya, dalam proses konflik hingga resolusi konflik, keberadaan pihak ketiga untuk memediasi dua pihak yang berkonflik sangat penting guna mengurangi kekerasan yang mana bisa dihasilkan dari konflik tersebut.

\section{Saran}

Berdasarkan hasil penelitian dan pembahasan serta temuan dilapangan mengenai tahapan konflik yang terjadi antara PT KAI Daop 2 Bandung dengan Warga Jalan Stasiun Barat, peneliti mengungkapkan beberapa saran yaitu:

1. Kepada intansi dan lembaga pemerintah maupun sosial untuk lebih gencar lagi dalam menjalankan peranannya sesuai dengan status masingmasing. Terutama kepada instansi pemerintah yang bertanggung jawab penuh dam memiliki hubungan langsung dengan masyarakat.

2. Kepada perusahaan/perseroan yang ingin mengklaim lahannya agar menujukkan bukti otentik mengenai kepemilikan lahannya terlebih dahulu. Kemudian, jika benar ada perampasan akan hak tanah yang dimiliki untuk merebutnya kembali haruslah melalui pengadilan sebagai 


\begin{tabular}{|c|c|c|c|c|}
\hline $\begin{array}{c}\text { Prosiding Penelitian \& } \\
\begin{array}{c}\text { Pengabdian Kepada } \\
\text { Masyarakat }\end{array}\end{array}$ & $\begin{array}{c}\text { e ISSN : 2581-1126 } \\
\text { p ISSN : 2442-448X }\end{array}$ & Vol 5, No: 2 & Hal: $102-110$ & Juli 2018 \\
\hline
\end{tabular}

lembaga hukum yang sah disepakati oleh seluruh masyarakat.

\section{DAFTAR PUSTAKA}

Bambang Rustanto. (2015). Penelitian Pekerjaan Sosial Pendekatan Kualitatif. Bandung: Rosda Karya

Benjamin. 2016. Kajian Disertasi "Konflik Antarwarga: Studi Kasus Konflik Antara Warga Desa Agom dan Warga Desa Balinuraga Kabupaten Lampung Selatan". Bandung: Universitas Padjadjaran

Budhi Wibawa, Santoso T. Raharjo, \& Meilany Budiarti S. (2010). Dasar-Dasar Pekerjaan Sosial. Bandung: Widya Padjadjaran.

Coser, Lewis. 1957. Social Conflict and The Theory of Social Change, British Journal of sociology 8:3

Creswell, John W. 2007. Research Design: Pendekatan Kualitatif, Kuantitaif, dan Mixed. Yogyakarta: Pustaka

Dahrendrof, Ralf. 1986. Konflik dalam Masyarakat Industri: Sebuah Analisa Kritik. Jakarta: Rajawali

Fisher, Simon. 2001. Mengelola Konflik: Keterampilan dan Strategi untuk Bertindak. The British Council

Galtung, Johan. 2000. Studi Perdamaian: Perdamaian dan Konflik. Jakarta:Eureka

G.Pruitt, Dean. Rubin, Jeffrey Z. 2004. Teori Konflik Sosial. Yogyakarta:Pustaka

Hanif, Emil Fauzan. 2014. Skripsi "Resolusi Konflik antara Warga Cigedug dan Warga Ahmadiyah Kabupaten Garut. Bandung: Universitas Padjadjaran.

Hendrajaya, dkk., Ragam Konflik di Indonesia: Corak Dasar dan Resolusinya, Badan Pembangunan dan Pengembangan Kementrian Pertahanan, 2010 diakses melalui http://km.ristek.go.id pada 11 April 2017 pukul 21:08 WIB

Hepworth, Dean H. Rooney, Ronald H. Larsen, Jo Ann. 2002. Direct Social Work Practice: Theory and Skills. United States of America: Brooks

Payne, Malcolm. 1997. Modern Social Work Theory. Chicago:Lyceum Books
Payne, Malcolm. 2016. Teori Pekerjaan Sosial Modern. Jakarta: Samudra Biru

\section{Rujukan Elektronik}

http://jabar.tribunnews.com/2016/08/31/penataankawasan-stasiun-barat-pt-kai-daop-2-bandungpasang-pagar diakses pada 4 Mei 2017 pukul 22.47 https://id.wikipedia.org/wiki/Kategori:Daerah_Oper asi_Kereta_Api_Indonesia diakses pada 29 Mei pukul 14.35

http://pembebasanbandung.blogspot.co.id/2016/11 /pt-kai-daop-ii-mangkir-pemkot-tak-serius.html diakses pada 2 Juni 2017 pukul 08.11

http://www.donisetyawan.com/cara-penyelesaiankonflik/ diakses pada 11 Juni pukul 21.09 